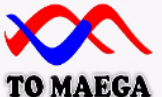

To Maega | Jurnal Pengabdian Masyarakat

Bulan-Tahun, Vol.3, No.2, hal. 130-141

$\operatorname{ISSN}(P): 2622-6332 ; \operatorname{ISSN}(E): 2622-6340$

http://www.ojs.unanda.ac.id/index.php/tomaega

\title{
Pelatihan Laporan Keuangan Bagi Pengurus BUM Desa Sekapur Sirih
}

\author{
Saipul Al Sukri1 1,a, , Asepma Hygi Prihastuti2,b, Julina ${ }^{3, c}$ \\ 1, 3 Program Studi Manajemen, Fakultas Ekonomi dan IImu Sosial UIN Suska Riau \\ 2 Program Studi akuntansi, Sekolah Tinggi Ilmu Ekonomi Persada Bunda \\ a,b,cEmail: saipul.alsukri@gmail.com; asepma.hygie@gmail.com; julina@uin- \\ suska.ac.id \\ *Correspondent Email: saipul.alsukri@gmail.com
}

\section{Article History:}

Received: 19-7-2020; Received in Revised: 21-7-2020; Accepted: 30-7-2020

DOI: http://dx.doi.org/10.35914/tomaega.v3i2.419

\begin{abstract}
Abstrak
Salah satu upaya yang bisa dilakukan dalam mengembangkan dan meningkatkan kesejahteraan ekonomi masyarakat desa adalah dengan mendorong gerak ekonomi desa melalui kewirausahaan. Kewirausahaan di desa dapat diwadahi dengan Badan Usaha Milik Desa (BUM Desa) yang dikembangkan oleh pemerintah dan masyarakat desa. BUM Desa Sekapur Sirih terletak di Kabupaten Pelalawan. Pengurus BUM Desa memiliki kewajiban membuat laporan keuangan sebagai bentuk pertanggungjawaban kepada seluruh masyarakat desa dan Kepala Desa. Rata-rata pengurus BUM Desa Sekapur Sirih tidak memiliki latar belakang pendidikan akuntansi dan mereka rata-rata hanya tamatan Sekolah Menengah Atas. Oleh sebab itu perlu dilakukan pelatihan laporan keuangan. Tujuan dari kegiatan ini adalah memberikan pengetahuan dan pemahaman pengurus tentang konsep akuntansi dan penyusunan laporan. Laporan Keuangan BUM Desa setidaknya terdiri atas buku kas harian, laporan rugi/laba dan laporan posisi keuangan. Metode yang digunakan dalam kegiatan ini adalah dengan penyampaian materi, tanya jawab dan simulasi. Hasil dari kegiatan pengabdian ini, pengurus sudah mampu memahami pentingnya membuat laporan keuangan, tujuan dan manfaat pencatatan, nomor golongan atau akun transaksi dan mencatat transaksi ke kas harian hingga menyusun laporan keuangan BUM Desa simpan pinjam.
\end{abstract}

Kata Kunci: Pelatihan, Laporan Keuangan, Unit Simpan Pinjam, BUM Desa.

\section{Abstract}

One effort that can be done in developing and improving the economic welfare of rural communities is to encourage the village economic movement through entrepreneurship. Entrepreneurship in villages can be accommodated with Badan Usaha Milik Desa (BUM Desa) developed by the government and village communities. BUM Desa Sekapur Sirih is located in Pelalawan Regency. BUM Desa Administrator has obligation to arrange financial statement as a form of responsibility to all village communities and the Village Head. Average of BUM Desa Sekapur Sirih Administrator does not have accounting background and they on only graduate from high school. Therefore, it is necessary to conduct financial statement training. The purpose of this activity is to provide BUM Desa Administrator knowledge and understanding of accounting concepts and report preparation. BUM Desa Financial Statement consist of daily cash book, income statement and statement of financial position. The method used in this training is giving theory, discussion and simulations. As a result of this training, the administrator 
[ 131 ] Penulis Pertama, dkk / To Maega : Jurnal Pengabdian Masyarakat, Vol..; No..,; Bulan, Tahun

has been able to understand how importance financial statement, the purpose and benefits of bookkeping and bookkeping transactions to daily cash book until financial statements of Savings and Loans BUM Desa.

Key Word: Training, Financial Reports, Savings and Loans Unit, BUM Desa.

\section{Pendahuluan}

Desa merupakan unit terkecil dari sebuah negara yang berhadapan langsung dengan masyarakat. Pengertian desa di dalam Undang-undang Desa Nomor 6 Tahun 2014, "Desa adalah kesatuan masyarakat hukum yang memiliki batas wilayah yang berwenang mengatur dan mengurus urusan pemerintahan, kepentingan masyarakat berdasarkan prakarsa masyarakat, hak asal usul, dan hak tradisional yang diakui dan dihormati dalam sistim pemerintahan negara." Dari informasi diatas dapat kita pahami bahwa desa dapat dikatakan sebagai wakil negara dalam tingkat terkecil dan memiliki kewajiban dalam melaksanakan pembangunan, baik yang berhubungan dengan pembangunan fisik maupun pembangunan non-fisik (pembangunan sumber daya manusia). Dengan adanya pembangunan, kesejahteraan masyarakat akan meningkat dan berujung pada pengurangan kemiskinan (Budiono, 2015), ditambah lagi 1 dari 4 anak di Indonesia mengalami Stunting pada tahun 2018 (Sukri, Syuryadi, \& Ernalia, 2020). Upaya ini akan sangat efektif jika dimulai dari desa, hal ini karena sebagian penduduk miskin memang berada di tingkat desa. Disamping itu, nilai gotong royong dan modal sosial (social capital) sangat memungkinkan untuk mendorong kemandrian masyarakat (komara, 2018). Tentu Semuanya dilakukan dalam upaya meningkatkan kualitas hidup dan kesejahteraan masyarakat desa (Budiono, 2015).

Menurut Ansari (2016) dan Putra (2015), salah satu upaya yang bisa dilakukan dalam mengembangkan dan meningkatkan kesejahteraan ekonomi masyarakat desa adalah dengan mendorong gerak ekonomi desa melalui kewirausahaan. Selanjutnya (Handono Eko Prabowo, 2014) menyampaikan kewirausahaan desa dapat diwadahi dalam Badan Usaha Milik Desa (BUM Desa). Perencanaan dan pendiriannya dibangun atas inisiasi masyarakat prinsip kooperatif, partisipatif, transparansi akuntabel (Hidayah et al., 2018). Menurut (Gunawan, 2011) BUM Desa merupakan wadah yang mampu menampung kegiatan peningkatan pendapatan masyarakat desa. Adanya BUM Desa diharapkan antar lembaga yang ada di masyarakat dapat saling bersinergi dalam memajukan kesejahteraan masyrakat (Zulkarnaen, 2016) dan mendorong gerak ekonomi desa melalui pemanfaatan potensi yang ada di desa (Kusuma, 2016).

Dalam UU No 6 tahun 2014 tentang Desa pada BAB X pasal 87 ayat 3 mengatakan "BUM Desa dapat menjalankan usaha di bidang ekonomi dan/atau pelayanan umum sesuai dengan ketentuan peraturan perundang-undangan”. Sebagai sebuah badan usaha, keberadaan BUM Desa kemudian di kuatkan lagi melalui Peraturan Menteri Desa Nomor 4 tahun 2015 tentang pendirian, 
pengurusan, pembubaran badan usaha milik desa, yang selanjutnya menjadi pedoman bagi pemerintah daerah dan desa dalam pembentukan dan pengurusan BUM Desa. Salah satu jenis usaha yang ada dalam BUM Desa dan lazim dijalankan di seluruh desa Kabupaten Pelalawan adalah unit usaha simpan pinjam. Usaha simpan pinjam yang menjadi bagian dari unit usaha BUM Desa yang berfungsi sebagai akses permodalan bagi masyarakat, menghindarkan masyarakat dari rentenir (Tampubolon, 2009), memperkuat ekonomi desa dan mendorong peningatan Pendapatan Asli Desa (Abidin, 2015). Sifat usaha BUM Desa haruslah berorientasi pada keuntungan, keterbukaan, kejujuran, partisipatif dan berkeadilan (Sujarweni, 2014). Selain itu keberadaan usaha simpan pinjam akan memberikan kesempatan berusaha bagi masyarakat yang tidak memiliki akses ke perbankan. Dengan menyediakan modal bagi masyarakat kelas bawah, unit usaha ini diharapkan mampu meningkatkan kegiatan ekonomi yang bersifat produktif di tingkat desa, sehingga dapat meningkatkan pendapatan masyarakat.

Dalam pelaksanaan kegiatan operasional sudah seharusnya sebuah organisasi/ badan memiliki sebuah laporan keuangan. Laporan keuangan adalah hal terpenting dalam sebuah organisasi guna memperoleh informasi mengenai posisi keuangan serta hasil yang dicapai. Laporan keuangan mencerminkan kondisinya selama periode tertentu (Irawati \& Martanti, 2017), menunjukkan pertanggungjawaban manajemen atau pengguna sumber daya yang dipercayakan kepada mereka. Sedarmayanti (2003) menyatakan bahwa transparansi dan akuntabilitas adalah dua kata kunci dalam penyelenggaraan pemerintahan maupun penyelenggaraan perusahaan yang baik (Good Governance). Selain itu menurut Auliyah (2012), laporan keuangan adalah salah satu bentuk informasi yang dapat digunakan untuk mengetahui kondisi dan perkembangan suatu organisasi atau perusahaan yang dilaporkan setiap akhir periode sebagai laporan pertanggung jawaban.

Dari laporan Kepala Desa dan Pendamping BUM Desa Sekapur Sirih didapat informasi bahwa selama 3 tahun ini pengurus BUM Desa tidak melaporkan pertanggungjawaban laporan keuangan BUM Desa dikarenakan adanya masalah internal organisasi. Kemudian dibentuklah pengurus BUM Desa baru yang rata-rata merupakan lulusan SMA/sederajat dan belum pernah sama sekali mempelajari mengenai penyusunan laporan keuangan, khususnya laporan keuangan BUM Desa. Pelaporan dalam sebuah organisasi merupakan suatu keniscayaan. Sudah menjadi kewajiban bagi pengurus untuk melaporkan laporan keuangan BUM Desa sebagaimana tertera dalam Permendesa No 4 Tahun 2015 pada bagian kedelapan pasal ke 31 ayat 1 disebutkan bahwa "pelaksana operasional melaporkan pertanggungjawaban pelaksanaan BUM Desa kepada penasihat yang secara ex-officio dijabat oleh Kepala Desa". Kemudian di ayat 3 di jelaskan lagi bahwa "pemerintah desa mempertanggung jawabkan tugas pembinaan terhadap BUM Desa kepada BPD yang disampaikan melalui musyawarah desa." 
Mengingat pentingnya laporan keuangan sebagai bentuk pertanggung jawaban pengurus, maka dipandang perlu bagi pengurus untuk memahami penyusunan laporan keuangan BUM Desa. Oleh sebab itu pengabdi melakukan pengabdian kepada masyarakat dengan judul "Pelatihan laporan keuangan bagi pengurus BUM Desa Sekapur Sirih Kabupaten Pelalawan".

\section{Metode}

Sasaran pelatihan ini adalah pengurus BUM Desa Sekapur Sirih, Desa Lubuk Mandian Gajah, Kecamatan Bunut, Kabupaten Pelalawan. Kegiatan pelatihan ini dilaksanakan satu hari penuh yang bertempat di aula kantor desa. Kegiatan dilaksanakan pada bulan November tahun 2019 yang lalu dan diikuti seluruh pengurus berjumlah 6 orang serta dihadiri oleh Kepala Desa dan Pendamping Desa. Sebelum melaksanakan kegiatan, pengabdi melakukan koordinasi terlebih dahulu dengan pendamping yang ada di kecamatan tersebut. Disana pendamping menentukan dan menetapkan waktu yang bersama dengan Kepala Desa dan pengurus BUM Desa. Metode yang dipilih dalam pelaksanaan pelatihan ini adalah:

a. Metode Ceramah

Metode ceramah dimaksudkan memberikan penjelasan mengenai materi pembukuan dalam sebuah presentasi meliputi; Kewajiban pelaporan keuangan, prinsip pembukuan, tujuan dan manfaat pencatatan, kaidah-kaidah akuntansi, nomor golongan atau akun, konsep dasar akuntansi dan alur penyusunan laporan. Penyusunan laporan menggunakan program microsoft Excel yang sudah saling terhubung antara sheet satu dengan yang lain, sehingga hanya dengan mengisi sheet pada kas harian maka secara ototmatis sheet berikutnya akan langsung berubah sesuai dengan perubahan angka di kas harian. Selain itu, juga diberikan kesempatan untuk melakukan tanya jawab untuk mengukur pemahaman atas materi yang disampaikan. Metode ini menggunakan bantuan laptop dan Infocus.

b. Metode Simulasi

Bagian ini penting untuk memberikan pengalaman langsung tentang bagaimana laporan keuangan disusun. Simulasi dilakukan dengan pemberian contoh-contoh transaksi yang umum terjadi di unit simpan pinjam. Diharapkan peserta dapat memahami lebih baik mulai dari pencatatan kas masuk, kas keluar serta menginput transaksi kedalam kas harian.

\section{Hasil dan Pembahasan}

Jauh sebelum adanya BUM Desa, Provinsi Riau telah memiliki Program Usaha Ekonomi Desa Simpan Pinjam (UED-SP). Program ini adalah sharing budget antara pihak Provinsi dan Kabupaten/Kota di Riau yang di prakarsai oleh Gubernur Rusli Zainal pada tahun 2005. Setiap desa saat itu mendapat dana bantuan sebesar Rp. 500.000.000 per desa. Khusus bagi Kabupaten Pelalawan, pada tahun itu setidaknya ada empat desa yang mendapat dana tersebut, yaitu Desa Sei Ara, Desa Rangsang, Desa Lubuk Mandian Gajah dan Desa Pompa Air (Kuala 
Semundam). Sebelum akhirnya program ini di hentikan, setidaknya hingga tahun 2014 sudah ada sekitar 68 desa di Kabupaten Pelalawan yang mendapatkan dana hibah tersebut.

Dalam perkembangannya, Desa Lubuk Mandian gajah mendirikan BUM Desa pada tahun 2016, dengan nama BUM Desa Sekapur Sirih.. Berikut ini adalah Struktur Organisasi BUM Desa Sekapur Sirih:

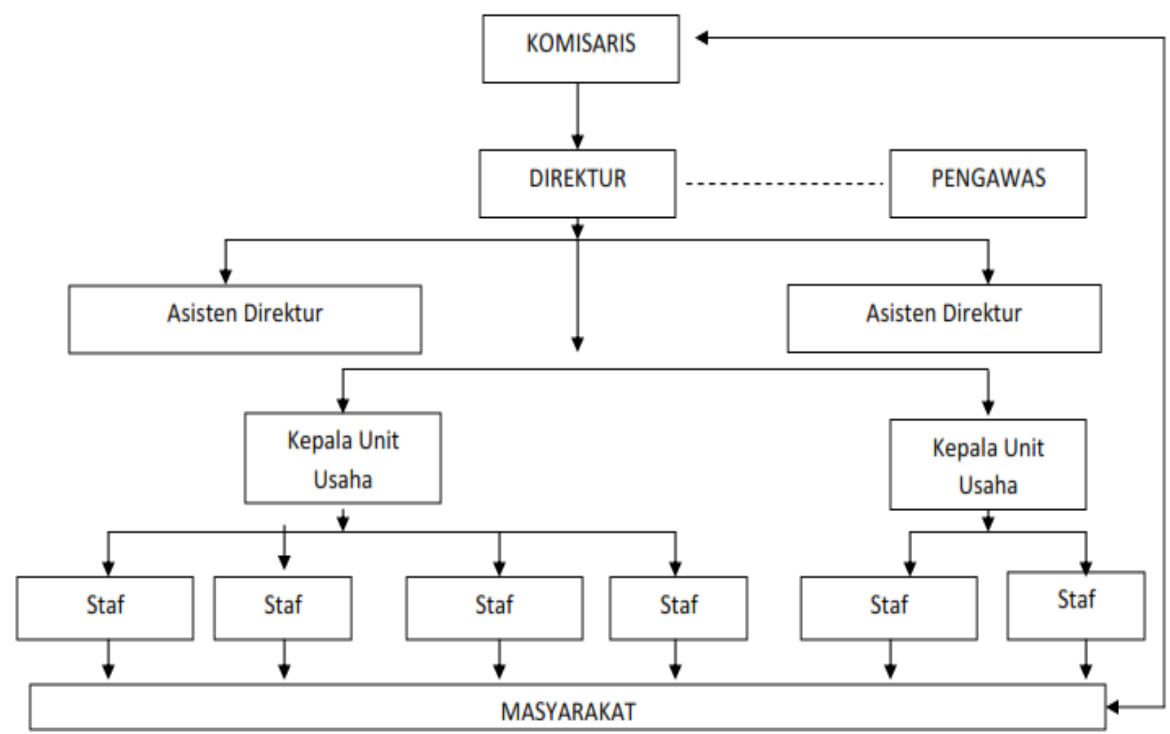

Gambar 1. Struktur Organisasi BUM Desa Sekapur Sirih

Mengenai laporan, pada prinsipnya transaksi keuangan pada BUM Desa Unit Simpan Pinjam ada 2 jenis, yaitu:

1) Transaksi Keuangan yang bersifat KAS, yaitu jenis transaksi keuangan yang transaksinya melalui kasir BUM Desa.

Contoh transaksi keuangan yang masuk ke Kas BUM Desa:

a) Bapak Makmur masuk menjadi anggota BUM Desa dan membayar uang simpanan awal sebesar Rp 50.000,-.

b) Pengurus mengambil uang Rp 250.000.000,- dari bank BUM Desa untuk dicairkan/ dipinjamkan kepada nasabah.

c) Menerima angsuran pokok dan jasa pinjaman dari nasabah setiap bulan.

Contoh Transaksi Keuangan yang keluar dari BUM Desa:

a) Pengurus menyetor uang tabungan dan simpanan anggota sejumlah $\mathrm{Rp}$ 55.000.000,- ke rekening BUM Desa.

b) Pengurus memberikan pinjaman kepada nasabah yang lolos oleh tim verifikasi.

c) Pengeluaran biaya transport untuk mengambil atau menyetor uang.

d) Pengeluaran insentif setiap bulan.

e) Sewa kantor atau biaya listrik yang dipakai oleh BUM Desa.

2) Transaksi Keuangan yang bersifat NON-KAS, yaitu jenis transaksi keuangan baik itu uang masuk atau keluar BUM Desa tanpa melalui kasir. 
[135] Penulis Pertama, dkk / To Maega : Jurnal Pengabdian Masyarakat, Vol..; No..; Bulan, Tahun

Contoh transaksi keuangan yang bersifat Non-Kas:

a) Transaksi pendapatan bunga bank, administrasi, dan pajak bank yang tercatat di rekening BUM Desa

b) Pembayaran angsuran pokok pemanfaat melalui transfer antar bank.

c) Penyusutan atas inventaris.

d) Pembelian inventaris secara kredit

Setiap transaksi yang bersifat kas harus dicatat ke dalam Kas Harian. Catatan kas harian akan diringkas lagi ke dalam daftar uang masuk (DUM) dan daftar uang keluar (DUK). kemudian baru dipindahkan ke neraca percobaan atau neraca lajur. Sedangkan untuk transaksi Keuangan yang bersifat non-kas atau Non Tunai dicatat ke "buku memorial atau jurnal memorial (JM)". Setelah tercatat ke JM, dengan cara yang sama pindahkan ke Neraca Percobaan. Hasil akhirnya adalah laporan rugi/laba dan laporan posisi keuangan/neraca.

Berikut Buku/Daftar Keuangan yang harus dimiliki oleh BUM Desa yang diadopsi dari Buku Panduan Pendirian dan Pengelolaan Badan Usaha Milik Desa (2007: 39-42) dengan beberapa penyesuaian sesuai kegiatan usaha BUM Desa Sekapur Sirih:

\section{Kas Harian}

Kas harian berfungsi untuk mencatat seluruh transaksi, baik transaksi peneriman atau transaksi pengeluaran kas. Hasil akhir buku ini adalah saldo akhir kas yang diperoleh dari Saldo awal ditambah jumlah penerimaan/pemasukan kas dikurangi jumlah pengeluaran kas. Buku kas harian harus mencatat transaksi keuangan secara kronologis dan tepat waktu. Kronologis artinya pencatatan transaksi berdasarkan urutan kejadian, sedangkan tepat waktu artinya pencatatan dilakukan saat terjadinya transaksi keuangan tersebut. Selain itu pencatatan pada kas harian haruslah disertai dengan bukti pendukung, seperti: kwitansi, faktur, slip bank. Berikut adalah Tabel 1 tentang format kas harian:

Tabel 1. Kas Harian

\begin{tabular}{|c|c||c|c|c|c|r|}
\hline Tgl & Uraian & Bukti & NP & Masuk & Keluar & Saldo \\
\hline & & & & & & \\
\hline & & & & & & 0 \\
\hline & & & & & & 0 \\
\hline & & & & & & 0 \\
\hline & & & & & & 0 \\
\hline & & & & & & 0 \\
\hline & & & & & & 0 \\
\hline & & & & & & 0 \\
\hline & & & & & & \\
\hline & & & & & & \\
\hline
\end{tabular}

Sumber: Buku Panduan Pendirian dan Pengelolaan Badan Usaha Milik Desa (2007: 39) 
[136] Penulis Pertama, dkk / To Maega : Jurnal Pengabdian Masyarakat, Vol..; No..; Bulan, Tahun

\section{Daftar Uang Masuk (DUM)}

Digunakan untuk memisahkan atau mengelompokkan semua transaksi penerimaan kas ke dalam masing-masing perkiraan. Misalnya : penerimaan simpanan anggota, angsuran pokok, angsuran bunga, dll.

\section{Daftar Uang Keluar (DUK)}

Digunakan untuk memisahkan semua transaksi pengeluaran kas ke dalam masing-masing perkiraan. Misalnya : penyetoran ke bank, pemberian pinjaman kepada anggota, bayar hutang ke pihak lain, bayar insentif pengelola, biaya transportasi, biaya ATK, dewa kantor, dll.

\section{Buku Memorial dan Jurnal Memorial}

Buku Memorial memuat catatan transaksi keuangan yang bersifat non-kas. Misalnya: bunga bank, biaya administrasi bank, transfer dana dari rekening pemanfaat ke rek BUM Desa, transfer dari rekening BUM Desa ke rekening Peminjam, dll. Buku ini sering dipakai untuk proses otomatisasi akuntansi, sedangkan yang melakukan sistem akuntansi dengan cara manual cukup mencatat transasksi tersebut di jurnal memorial.

Tabel 2. Buku Memorial

\begin{tabular}{|r|l|r|r|l|l|}
\hline Tgl & \multicolumn{1}{|c|}{ Uraian } & Bukti & NP & Debit & Kredit \\
\hline 1 & Bank RIAU & & 121 & & \\
\hline 2 & Bank Rek ... & & 122 & & \\
\hline 3 & Transfer dari rek nasabah ke rek Bumdes & & 131 & & \\
\hline 4 & Transfer dari rek nasabah ke rek Bumdes & & 132 & & \\
\hline 5 & Pendapatan Bunga Bank RIAU & & 421 & & \\
\hline 6 & Pajak dan Administrasi Bank RIAU & & 531 & & \\
\hline 7 & Akum. Laba sd Bulan ini & & 316 & & \\
\hline 8 & Cadangan Modal & & 314 & & \\
\hline 9 & Laba Yang Akan Dibagikan & & 217 & & \\
\hline 10 & Penyusutan & & 524 & & \\
\hline 11 & Ak. Peny Bangunan & & 146 & & \\
\hline 12 & Ak. Peny Kendaraan & & 147 & & \\
\hline 13 & Ak. Peny Meubel dan perabotan & & 148 & & \\
\hline 14 & Ak. Peny Inventaris Kantor & & 149 & & \\
\hline 15 & Pembelian Kendaraan secara kredit & & 143 & & \\
\hline 16 & Pembelian Meubel dan perabotan secara kredit & & 144 & & \\
\hline 17 & Pembelian Inventaris Kantor secara kredit & & 145 & & \\
\hline 18 & Beban bunga pinjaman Bank & & 511 & & \\
\hline \multicolumn{2}{|l|}{ Jumlah } & & & \\
\hline
\end{tabular}

Sumber: Pengembangan Buku Panduan Pendirian dan Pengelolaan Badan Usaha Milik Desa (2007: 42)

\section{Neraca Percobaan (LKN)}

Neraca percobaan yang dipakai di akuntansi BUM Desa terdiri dari 3 kolom, yaitu saldo awal, mutasi, dan saldo akhir. Setiap kolom terdiri dari dua kolom yaitu kolom debet dan kolom kredit, sehingga total kolom lembar kerja neraca (LKN) sebanyak enam kolom. Neraca prcobaan digunakan untuk mencatat 
perubahan setiap perkiraan yang dipengaruhi oleh terjadinya mutasi (perubahan perkiraan debet maupun kredit) akibat adanya transaksi keuangan.

Angka-angka pada saldo awal di ambil dari angka-angka saldo akhir pada neraca percobaan pada bulan lalu. Angka-angka pada mutasi di ambil dari angkaangka yang ada pada DUM-DUK dan jurnal memorial atas transaksi keuangan yang terjadi pada bulan berjalan. Angka pada saldo akhir merupakan penjumlahan dan pengurangan antara saldo awal dengan mutasi.

\section{Laporan Rugi /Laba}

Laporan rugi/laba merupakan laporan yang mencatat semua pendapatan dan biaya pada periode tertentu. Laporan rugi/laba pada BUM DESA terdiri dari 2 jenis, yaitu rugi/laba bulanan dan komulatif. Rugi/laba bulanan di ambil dari angka-angka pendapatan dan biaya di kolom mutasi. Rugi/laba komulatif di ambil dari angka-angka pendapatan dan biaya di kolom saldo akhir. Berikut disajikan rumus untuk menghitung Rugi/Laba, baik bulanan maupun komulatif.

Tabel 3. Laporan Laba Rugi

Bulanan (Periode : $1 \mathrm{~s} / \mathrm{d} 31$ Desember 2018)

Kumulatif (Periode : 1 Januari s/d 31 Desember 2018)

\begin{tabular}{|c|c|c|c|}
\hline 4 & PENDAPATAN SIMPAN PINJAM & & \\
\hline 411 & Jasa Pinjaman Modal kerja & $R p$ & - \\
\hline 412 & Jasa Pinjaman Konsumtif & $R p$ & - \\
\hline 413 & Jasa Pinjaman Modal Zakat & $R p$ & - \\
\hline 421 & Bunga Bank & $R p$ & - \\
\hline 422 & Denda & $R p$ & - \\
\hline 423 & Provisi/pendapatan lain-lain & $R p$ & - \\
\hline & TOTAL PENDAPATAN & $R p$ & - \\
\hline 5 & BEBAN BUNGA POKOK & & \\
\hline 511 & Beban Bunga Pinjaman Bank & & - \\
\hline 512 & Beban jasa simpanan & $R p$ & - \\
\hline & JUMLAH BEBAN POKOK & $R p$ & - \\
\hline & LABA (RUGI) KOTOR & $R p$ & - \\
\hline 52 & BEBAN USAHA & & \\
\hline 521 & Honor Direktur, KU, Staff, Komisaris dan Pengawas & $R p$ & - \\
\hline 522 & Adm dan Umum & $R p$ & - \\
\hline 523 & Transport & $R p$ & - \\
\hline 524 & Penyusutan & $\mathrm{Rp}$ & - \\
\hline 525 & Lain-lain & $R p$ & - \\
\hline 531 & Adm dan Pajak Pendapatan Bunga Bank & $R p$ & - \\
\hline & JUMLAH BEBAN USAHA & $R p$ & - \\
\hline & LABA (RUGI) USAHA & $\mathrm{Rp}$ & - \\
\hline
\end{tabular}

\begin{tabular}{|c|c|c|c|}
\hline 4 & PENDAPATAN SIMPAN PINJAM & & \\
\hline 411 & Jasa Pinjaman Modal kerja & $R p$ & \\
\hline 412 & Jasa Pinjaman Konsumtif & $\mathrm{Rp}$ & - \\
\hline 413 & Jasa Pinjaman Modal Zakat & $R p$ & - \\
\hline 421 & Bunga Bank & $\mathrm{Rp}$ & \\
\hline 422 & Denda & $R p$ & - \\
\hline 423 & Provisi/pendapatan lain-lain & $R p$ & - \\
\hline & TOTAL PENDAPATAN & $R p$ & \\
\hline & & & \\
\hline 5 & BEBAN BUNGA POKOK & & \\
\hline 511 & Beban Bunga Pinjaman Bank & & - \\
\hline 512 & Beban jasa simpanan & $R p$ & - \\
\hline & JUMLAH BEBAN POKOK & $\mathrm{Rp}$ & - \\
\hline & LABA (RUGI) KOTOR & $\mathrm{Rp}$ & - \\
\hline 52 & BEBAN USAHA & & \\
\hline 521 & Honor Direktur, KU, Staff, Komisaris dan Pe & $R p$ & \\
\hline 522 & Adm dan Umum & $\mathrm{Rp}$ & - \\
\hline 523 & Transport & $\mathrm{Rp}$ & - \\
\hline 524 & Penyusutan & $\mathrm{Rp}$ & - \\
\hline 525 & Lain-lain & $R p$ & - \\
\hline 531 & Adm dan Pajak Pendapatan Bunga $B$ & $R p$ & \\
\hline & JUMLAH BEBAN USAHA & $\mathrm{Rp}$ & \\
\hline & LABA (RUGI) USAHA & $\mathrm{Rp}$ & \\
\hline
\end{tabular}

Sumber: Buku Panduan Pendirian dan Pengelolaan Badan Usaha Milik Desa (2007: 42)

\section{Laporan Posisi Keuangan/Neraca}

Neraca merupakan posisi aktiva, hutang, dan modal pada tanggal tertentu. Angka-angkanya diambil dari angka-angka pada saldo Akhir pada neraca percobaan/LKN. Khusus untuk perkiraan akumulasi rugi/laba s/d bulan berjalan pada neraca BUM Desa di ambil dari laporan rugi/laba komulatif'. Angka yang 
[138 ] Penulis Pertama, dkk / To Maega : Jurnal Pengabdian Masyarakat, Vol..; No..; Bulan, Tahun

diambil adalah selisih dari jumlah pendapatan komulatif dikurangi dengan jumlah biaya komulatif, dan angka ini dinamakan rugi/laba Komulatif.

Tabel. 4 Neraca

\begin{tabular}{|c|c|c|c|}
\hline \multicolumn{4}{|c|}{ AKTIVA } \\
\hline 1 & AKTIVA LANCAR & & \\
\hline 110 & Kas & $\mathrm{Rp}$ & 0 \\
\hline 120 & Bank & $\mathrm{Rp}$ & 0 \\
\hline 130 & Piutang Usaha & $\mathrm{Rp}$ & 0 \\
\hline 134 & Piutang Unit Lain & $R p$ & 0 \\
\hline \multirow[t]{2}{*}{135} & Biaya dibayar dimuka & $\mathrm{Rp}$ & 0 \\
\hline & JUMLAH AKTIVA LANCA & $\mathrm{Rp}$ & 0 \\
\hline 14 & AKTIVA TETAP & & \\
\hline 141 & Tanah & $R p$ & 0 \\
\hline 142 & Bangunan & $\mathrm{Rp}$ & 0 \\
\hline 143 & Kendaraan & $\mathrm{Rp}$ & 0 \\
\hline 144 & Meubel dan perabotan & $\mathrm{Rp}$ & 0 \\
\hline 145 & Inventaris Kantor & $R p$ & 0 \\
\hline 146 & Akumulasi Penyusutan & $R p$ & 0 \\
\hline \multicolumn{2}{|c|}{ Nilai Buku } & $\mathrm{Rp}$ & 0 \\
\hline & & & \\
\hline 16 & AKTIVA LAIN-LAIN & & \\
\hline 161 & Aktiva Lain-lain & $\mathrm{Rp}$ & 0 \\
\hline & JUMLAH AKTIVA & $R p$ & 0 \\
\hline
\end{tabular}

\begin{tabular}{|c|c|c|c|}
\hline \multicolumn{4}{|c|}{ PASSIVA } \\
\hline 2 & HUTANG LANCAR & & \\
\hline 210 & Hutang Simpanan & $\mathrm{Rp}$ & 0 \\
\hline 213 & hutang terhadap jasa simpanan & $\mathrm{Rp}$ & 0 \\
\hline 214 & Hutang Bunga & $\mathrm{Rp}$ & 0 \\
\hline 215 & Hutang Pihak Ketiga & $R p$ & 0 \\
\hline 216 & Pendapatan di terima dimuka & $\mathrm{Rp}$ & 0 \\
\hline 217 & Laba Yang Akan Dibagikan & $\mathrm{Rp}$ & 0 \\
\hline 218 & Titipan & $\mathrm{Rp}$ & 0 \\
\hline & JUMLAH HUTANG LANCAR & $R p$ & 0 \\
\hline 22 & HUTANG JANGKA PANJAN & & \\
\hline 221 & Hutang Bank Jangka Panjang & $\mathrm{Rp}$ & 0 \\
\hline & JUMLAH HUTANG & $R p$ & 0 \\
\hline 3 & MODAL & & \\
\hline 310 & Modal Dasar & $\mathrm{Rp}$ & 0 \\
\hline 314 & Cadangan Modal & $\mathrm{Rp}$ & 0 \\
\hline 315 & Laba tahun Lalu & $\mathrm{Rp}$ & 0 \\
\hline 316 & Akum. laba sd bln berjalan & $\mathrm{Rp}$ & 0 \\
\hline & JUMLAH MODAL & $\mathrm{Rp}$ & 0 \\
\hline & JUMLAH PASSIVA & $\mathrm{Rp}$ & 0 \\
\hline
\end{tabular}

Sumber: Buku Panduan Pendirian dan Pengelolaan Badan Usaha Milik Desa (2007: 41)

Suasana pelatihan dilakukan secara serius tapi santai. Kegiatan tersebut dapat terlihat dari foto berikut:

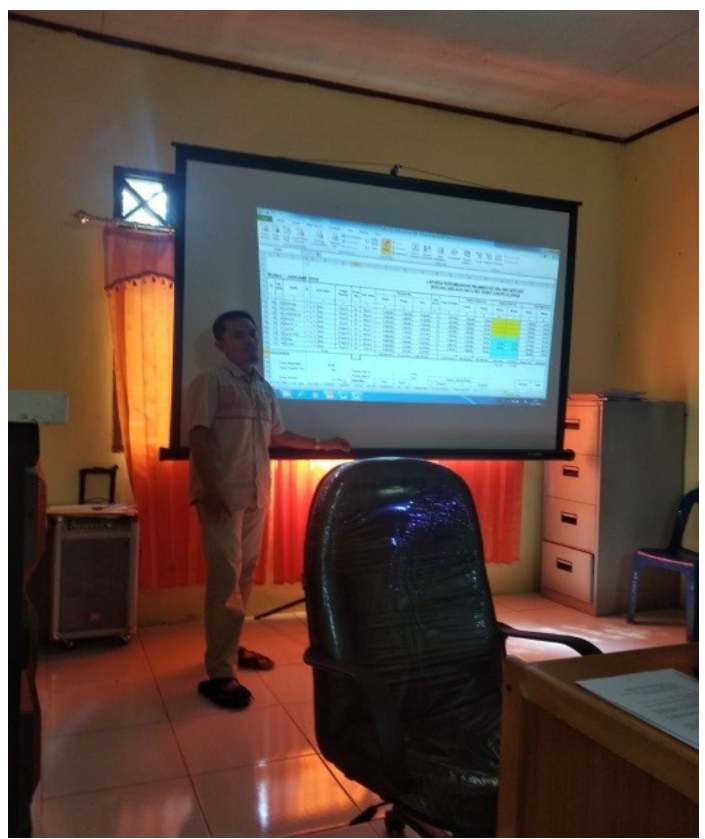

Foto 1. Pemberian materi 
Penekanan dalam kas harian menjadi lebih kuat ketika mempelajari penomoran akun. Dalam hal tim pengabdi menggunakan persamaan lima jari (warsono dan irene, 2011), dimana peserta dapat mengenal akun (kode 1) untuk akun aset, (kode 2) liabilitas, (kode 3) ekuitas. (kode 4) pendapatan, dan kode (5) untuk akun beban. Penggunaan kode lebih mempermudah dalam mengenali akun pada setiap jenis transaksi.

Kesungguhan peserta dalam melakukan simulasi laporan dapat terlihat dari foto dibawah:

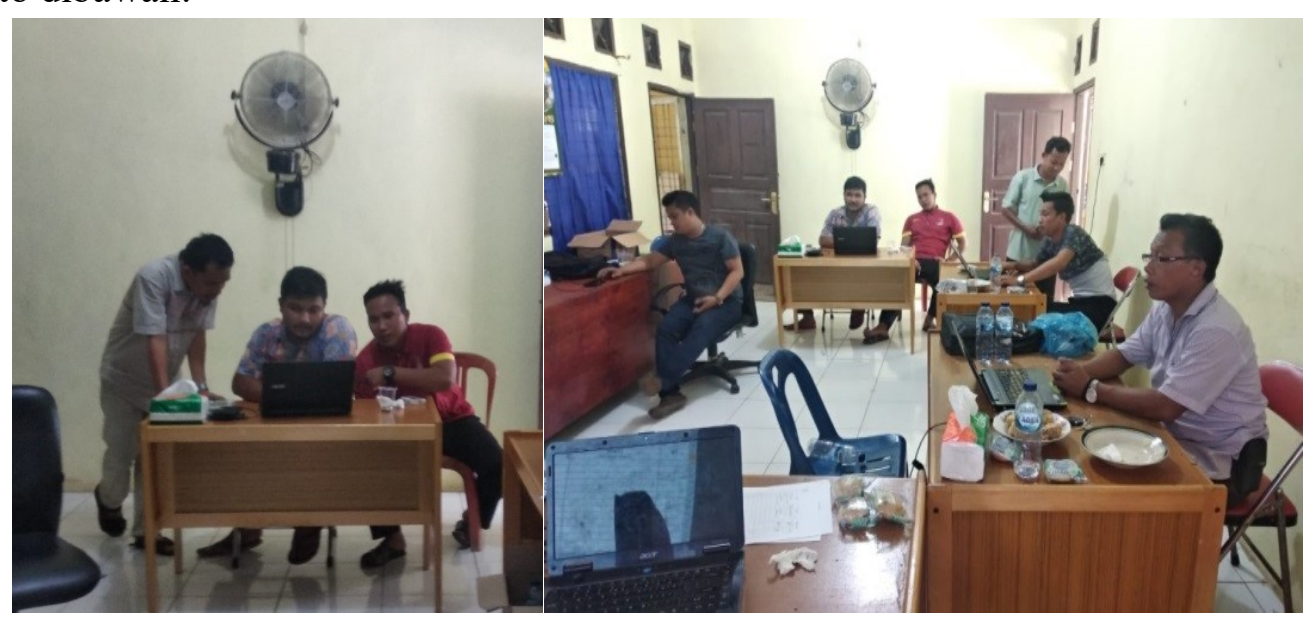

Foto 2. Simulasi penyusunan laporan keuangan

Diakhir pelatihan pengabdi bersama pengurus menyempatkan sesi foto bersama seperti terlihat pada foto berikut:

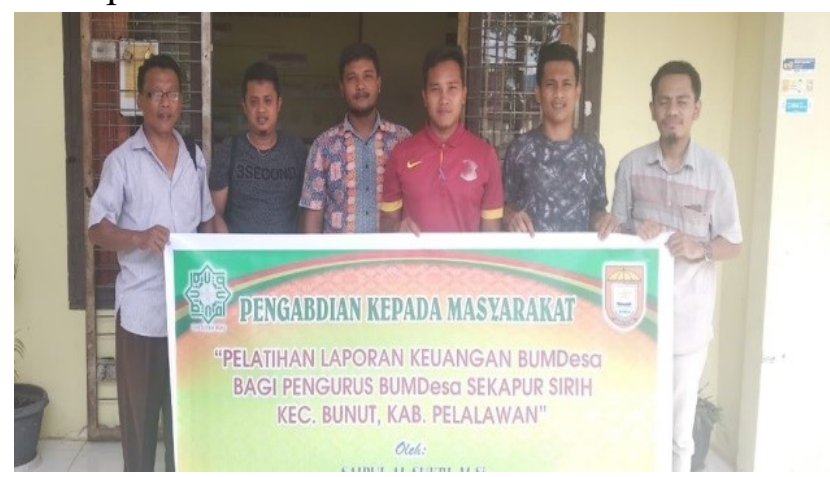

Foto 3. Foto bersama setelah kegiatan pelatihan

\section{Kesimpulan}

BUM Desa sebagai kekuatan perekonomian baru di desa mempunyai peran ganda, baik sebagai lembaga komersial (commercial institution) maupun sebagai lembaga sosial (social institution) melalui usaha-usaha ekonomi yang berbasiskan pemberdayaan. Laporan keuangan adalah hasil dari proses pencatatan dan pengikhtisaran transaksi bisnis yang digunakan sebagai alat komunikasi dan pengambilan keputusan bagi pihak yang berkepentingan. Laporan BUM Desa juga bisa dikatakan sebagai tolak ukur bagi pihak eksternal untuk melihat dan menilai kondisi keuangan BUM Desa pada setiap periode. 
Hasil yang dapat dicapai dari kegiatan pelatihan ini antara lain pengurus sudah mampu memahami pentingnya membuat laporan keuangan, tujuan dan manfaat pencatatan, nomor golongan atau akun transaksi dan mencatat transaksi ke kas harian hingga menyusun laporan keuangan BUM Desa simpan pinjam. Bimbingan selanjutnya akan terus dilakukan dalam rangka meningkatkan pengetahuan dan mengevaluasi hasil kerja pengurus sehingga semakin lancar dan mahir dalam pembuatan laporan.

\section{Ucapan Terimakasih}

Ucapan terima kasih kami sampaikan kepada Lembaga Penelitian dan Pengabdian (LPPM) Universitas Islam Negeri Sultan Syarif Kasim Riau yang telah memberikan kepercayaan kepada pengabdi untuk melaksanakan kegiatan pengabdian ini. Selanjutnya terima kasih kami kepada Pemerintahan Desa Lubuk Mandian Gajah dan Pengurus BUM Desa Sekapur Sirih yang telah berpartisipasi aktif sampai terlaksananya kegitan ini.

\section{Daftar Pustaka}

Abidin, M. Z. (2015). Tinjauan Atas Pelaksanaan Keuangan Desa dalam Mendukung Kebijakan Dana Desa. Jurnal Ekonomi \& Kebijakan Publik. https://doi.org/http://dx.doi.org/10.22212/jekp.v6i1.156

Auliyah, I. (2012). Penerapan Akuntansi Berdasarkan SAK ETAP pada ukm kampung batik di sidoarjo (Doctoral dissertation, STIE Perbanas Surabaya).

Budiono, P. (2015). Implementasi Kebijakan Badan Usaha Milik Desa (Bumdes) Di Bojonegoro (Studi di Desa Ngringinrejo Kecamatan Kalitidu Dan Desa Kedungprimpen Kecamatan Kanor). Jurnal Politik Muda, 4(1), 116-125

Departemen Pendidikan Nasional, Pusat Kajian Dinamika Sistem Pembangunan (PKDSP). 2007. Buku Panduan Pendirian dan Pengelolaan Badan Usaha Milik Desa (BUM Desa). Fakultas Ekonomi Universitas Brawijaya.

Gunawan, K. (2011). Manajemen BUMDES Dalam Rangka Menekan Laju Urbanisasi. WIDYATECH Jurnal Sains Dan Teknologi 10(3).

Handono Eko Prabowo, T. (2014). Developing bumdes (village-owned enterprise) for sustainable poverty alleviation model village community study in Bleberan-Gunung Kidul-Indonesia. World Applied Sciences Journal. https://doi.org/10.5829/idosi.wasj.2014.30.icmrp.4

Hidayah, A. T., Pujiati, L., Hidyati, N., Hendrawan, S. A., Suprapto, S., \& Ali, N. (2018). Pendampingan Penyusunan Laporan Keuangan Pada Badan Usaha Milik Desa (Bumdes) Lestari Desa Bandung Kecamatan Diwek Jombang. Comvice: Journal of Community Service. https://doi.org/10.26533/comvice.v2i1.123

Irawati, D., \& Martanti, D. E. (2017). Transparasi pengelolaan laporan keuangan Bumdes terhadap pelaporan aset desa. Strategi Pengelolaan Sumber Daya Daerah Dalam Menciptakan Good Governance.

Komara, E. K. (2015). Manfaat Badan Usaha Milik Desa (BUM Desa) bagi 
[ 141 ] Penulis Pertama, dkk / To Maega : Jurnal Pengabdian Masyarakat, Vol..; No..; Bulan, Tahun

Masyarakat (Telaah Kajian Manfaat Keberadaan BUM Desa 'Hanyukupi'Ponjong dan BUM Desa 'Sejahtera'Bleberan di Kabupaten Gunungkidul). Yayasan Penabulu.

Kusuma, G. H., \& Purnamasari, N. (2016). BUMDES: Kewirausahaan Sosial yang Berkelanjutan (Analisis Potensi dan Permasalahan yang dihadapi Badan Usaha Milik Desa di Desa Ponjong, Desa Bleberan, dan Desa Sumbermulyo). Yayasan Penabulu.

Peraturan menteri Desa, PDT dan Transmigrasi No. 4 Tahun 2015. Tentang pendirian, pengurusan dan pengelolaan dan pembubaran badan usaha milik desa.

Sedarmayanti. (2003). Good Governance (Kepemerintahan Yang Baik) Dalam Rangka Otonomi Daerah. Bandung: Mandar Maju.

Sujarweni, V. Wiratna, 2014, Akuntansi Desa, Pustaka Baru.

Sukri, S. Al, Syuryadi, N., \& Ernalia, Y. (2020). Peningkatan Pengetahuan Gizi Seimbang Dan Mitos Seputar Gizi Pada Keluarga Pra-Sejahtera. Martabe: Jurnal Pengabdian Kepada Masyarakat, 3(1), 108-115.

Tampubolon, D. (2009). Lembaga Keuangan Mikro Pedesaan Di Kabupaten Bengkalis. Jurnal Ekonomi, 17(01).

Undang-undang No.6 tahun 2014 tentang Desa

Warsono, S. dan Natalia, I. (2011). Akuntansi Pengantar 1: Sistem Penghasil Informasi Keuangan, ABPublisher, Yogyakarta.

Zulkarnaen, R. M. (2016). Pengembangan potensi ekonomi desa melalui badan usaha milik desa (Bumdes) Pondok Salam Kabupaten Purwakarta. Jurnal Aplikasi Ipteks Untuk Masyarakat, 6(1), 61-76. 